\title{
Marvin Frankel's Mistakes and the Need to Rethink Federal Sentencing
}

\author{
Lynn Adelman $\uparrow$ and Jon Deitrich
}

\section{FATHER OF THE GUIDELINES}

November 1, 2007, marked the twentieth anniversary of the effective date of the federal sentencing guidelines. As far as we know, no one held any celebrations commemorating the occasion. Students of federal sentencing generally agree that at least prior to United States v. Booker, ${ }^{1}$ the guidelines failed. Two scholars called the guidelines "one of the great failures at law reform in U.S. history." 2 Another characterized them as the most "disliked sentencing reform initiative in this century," 3 and a fourth stated that "[d]espite its hopeful beginnings, the federal sentencing system as constituted before Booker failed." 4

The sequence of events that led to the guidelines is well known to students of federal sentencing. After debating the issue of sentencing for a number of years, Congress enacted the Sentencing Reform Act of 1984 ("SRA"), in which it abolished parole, provided for appellate review of sentencing, created the United States Sentencing Commission ("Commission") and directed the

$\dagger \quad$ United States District Court Judge for the Eastern District of Wisconsin; former Wisconsin legislator.

* Law Clerk, Judge Lynn Adelman; Adjunct Professor of Law, Marquette University Law School. The authors wish to thank Professor Michael O'Hear of Marquette University Law School for his comments on a draft of this article. Any errors are, of course, our own.

1. 543 U.S. 220 (2005) (holding that the federal sentencing guidelines violated a defendant's Sixth Amendment right to trial by jury because they required judges to find facts that exposed defendants to increased prison time. The Supreme Court solved the problem by making the guidelines advisory rather than mandatory).

2. Marc L. Miller and Ronald F. Wright, Your Cheatin' Heart(land): The Long Search for Administrative Sentencing Justice, 2 BUFF. CRIM. L. REV. 723, 726 (1999).

3. Michael Tonry, The Success of Judge Frankel's Sentencing Commission, 64 U. COLO. L. REV. 713, 716 (1993).

4. Frank O. Bowman, III, Mr. Madison Meets a Time Machine: The Political Science of Sentencing Reform, 58 STAN. L. REV. 235, 246 (2005). 
Commission to promulgate binding guidelines. ${ }^{5}$ In the SRA, Congress sought to achieve "certainty and fairness" by eliminating "unwarranted disparity" among sentences for similar defendants committing similar offenses. ${ }^{6}$ In 1987 , the Commission completed the guidelines. ${ }^{7}$

The most important legal intellectual in the movement leading to the creation of the guidelines was Judge Marvin E. Frankel of the Southern District of New York. $^{8}$ In 1973, Frankel, a former administrative law professor at Columbia Law School, published a book, Criminal Sentences: Law Without Order. In the book, Frankel indicted the broad sentencing discretion enjoyed by judges and called for the creation of an administrative agency to enact rules governing sentencing. Frankel's ideas were enormously influential, prompting Senator Edward M. Kennedy, the SRA's principal sponsor, to call Frankel the "father of sentencing reform." In their important study of the guidelines, Professor Stith and Judge Cabranes called Frankel's arguments the "most influential of all criticisms of judicial sentencing discretion." 10

Congress and the Commission's failure to establish a sentencing system that scholars and practitioners regarded as fair bitterly disappointed many who, inspired by Frankel's ideas, viewed imposing limitations on judicial sentencing discretion as a great step forward. As Marc L. Miller and Ronald F. Wright put it, "[t]he disaster is all the more disheartening because the reform started out with so much promise." 11

Commentators disagree about why the guidelines failed. Professor Stith and Steve Y. Koh argue that Congress required the Commission to establish guidelines that were so harsh and rigid that they were doomed to fail:

[W] hatever early proponents of guidelines may have expected, it is clear that Congress desired a significant degree of rigidity and harshness in the sentencing guidelines. Many provisions of the statute either mandate or strongly encourage the policy choices that the Commission made - including the Commission's decision to view the relevancy of personal characteristics with skepticism, its decision to develop a large number of severity levels, and, more generally, its decision not to be bound by past sentencing practices. ... It is ... no accident that the percentage of defendants being imprisoned and the length of prison terms have increased; a multitude of provisions in the Sentencing Reform Act and subsequent statutes clearly point in this

5. Kate Stith and José A. Cabranes, Fear of JudGing: Sentencing Guidelines in THE FEDERAL COURTS 2 (The University of Chicago Press 1998).

6. Id. (citing S. REP. NO. 225, 98th Cong., 1st Sess. 52, 56 (1984)).

7. Id. at 1 .

8. Id. at 35 .

9. Id.

10. Id.

11. Miller and Wright, supra note 2, at 723. 
direction. ${ }^{12}$

Others place primary responsibility on the Commission. Michael Tonry argues that the Commission failed because it was insufficiently insulated from politics. He writes that:

[The Commission] made no effort to insulate its policies from politics and superficial emotion. . . . [It] apparently decided that the Department of Justice and the most law-and-order members of the United Sates Congress were its primary constituency and it established and attempted to enforce policies that pleased that constituency. This is presumably why the commission ignored a statutory presumption against incarceration of first offenders not convicted of violent or other serious crimes, and why it reacted to harsh mandatory minimum penalty provisions for many drug offenses by making the guidelines even harsher. ${ }^{13}$

No one seems to attribute the guidelines' failure to deficiencies in Frankel's ideas about sentencing or in his proposed reforms. Despite dissatisfaction with the guidelines, judges and academics who have written about sentencing treat Frankel as an icon and accept the notion that sentencing should be governed by commissions which promulgate numerical guidelines that constrain judges. For example, Judge Gerard E. Lynch, who has written extensively about sentencing, recently remarked that he favored guidelines ever "since I was a law student and read Marvin Frankel's book." 14 And Judge Nancy Gertner, who writes persuasively about the failure of Congress, the Commission and the judiciary in connection with the guidelines, places no responsibility on Frankel. ${ }^{15}$ And another thoughtful student of federal sentencing, Michael M. O'Hear, opined that "Judge Frankel's vision of a more humane and dignified sentencing process remains a compelling one."16

We agree that Frankel was a brilliant professor and a distinguished judge and that Congress and the Commission implemented his ideas poorly. We also agree that he wanted sentencing to be more humane. ${ }^{17}$ However, we believe that Frankel's analysis of sentencing was deeply flawed, and that the guidelines failed in substantial part because of the flaws in his approach. We also believe that discussing Frankel's ideas is timely, both because of the recent Supreme

12. Kate Stith and Steve Y. Koh, The Politics of Sentencing Reform: The Legislative History of the Federal Sentencing Guidelines, 28 WAKE FOREST L. REV. 223, 284 (1993).

13. Tonry, supra note 3 , at 716-17.

14. Panel Discussion, Federal Sentencing Under "Advisory Guidelines": Observations by District Judges, 75 FORDHAM L. REV. 1, 14 (2006) (hereafter "Panel Discussion").

15. See, e.g., Nancy Gertner, Sentencing Reform: When Everyone Behaves Badly, 57 ME. L. REV. 569 (2005).

16. Michael M. O'Hear, The Original Intent of Uniformity in Federal Sentencing, 74 U. CIN. L. REV. 749 (2006).

17. See Marvin E. Frankel \& Leonard Orland, A Conversation About Sentencing Commissions and Guidelines, 64 U. COLO. L. REV. 655, 659 (1993). 
Court decisions returning sentencing discretion to district judges ${ }^{18}$ and because of the recent interest in the problem of mass incarceration ${ }^{19}$ to which the guidelines have contributed. ${ }^{20}$ In this article, we discuss Frankel's ideas, the problems with them, and their effects. We conclude with several recommendations as to how to improve federal sentencing.

\section{FRANKEL'S BASIC APPROACH}

Frankel regarded broad judicial sentencing discretion of the type that existed in the pre-guideline system of indeterminate sentencing as "lawless." 21 He believed that, in a democracy, the rule of law required judges to resolve legal issues in conformity with a specific adjudicative model. ${ }^{22}$ That model involved legislatures and/or administrative agencies enacting rules, and judges resolving questions by applying such rules. ${ }^{23}$ Frankel argued that because legislatures had not provided sufficiently specific directives to judges concerning sentencing or created sentencing commissions that provided such directives, judges had too much discretion and as a result, made decisions based on subjective factors. ${ }^{24}$ Sentences based on such factors were necessarily

18. See Gall v. United States, 128 S. Ct. 586 (2007); Kimbrough v. United States, 128 S. Ct. 558 (2007); Rita v. United States, 127 S. Ct. 2456 (2007); United States v. Booker, 543 U.S. 220 (2005).

19. A number of scholars have recently written about various aspects of this problem. See, e.g., SASHA ABRAMSKy, AMERICAN FURIES: CRIME, PUNISHMENT AND VENGEANCE IN THE AGE

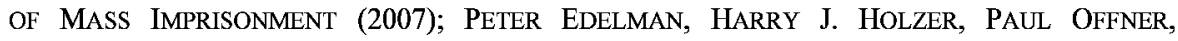
RECONNECTING DisAdVANTAGED YOUNG MEN (2006); DAVID GaRLand, THE CUltuRE of CONTROL, CRIME AND SOCIAL ORDER IN CONTEMPORARY SOCIETY (2001); MARIE

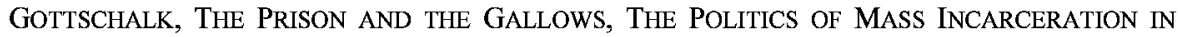
AMERICA(2006); INVISIBLE PUNISHMENT: THE COLLATERAL CONSEQUENCE OF MASS INCARCERATION (Marc Mauer and Meda Chesney-Linel eds., 2003); DEVAH PAGER, MARKED: RACE, CRIME, AND FINDING WORK IN AN ERA OF MASS INCARCERATION (2007); JONATHAN SIMON, GOVERNING THROUGH CRIME (2007); BRUCE WESTERN, PUNISHMENT AND INEQUALITY IN AMERICA (2006); JAMES G. WhitMan, HaRSh Justice: CRIMINAL PUNISHMENT AND tHe WIDENING DIVIDE BETWEen AMERICA AND EuRoPe (2003); Glen C. Loury, Why Are So Many Americans in Prison, Race and the Transformation of Criminal Justice, BOSTON REVIEW, July/August 2007.

20. See Nora V. Demleitner, Smart Public Policy: Replacing Imprisonment With

Targeted Nonprison Sentence and Collateral Sanctions, 58 STAN. L. REV. 339, 339 (2005) (stating that in the last two decades, the rate of imprisonment in federal cases has sharply increased) (citing Paige M. Harrison \& Allen J. Beck, Bureau of Justice Statistics, Prison \& Jail inmates at Midyear 2004 at 2-4 \& tables 1-2 (2005), http://www.ojp.usdoj.gov/bjs/pub/pdf/pjim04 .pdf (last visited Sept. 25, 2005) (stating that between 1995 and 2004, the federal correctional population increased annually by an average of $7.8 \%$ while the states added $2.7 \%$ inmates per year)).

21. MARVIN Frankel, CRIMINAL SENTENCES: LAW Without ORdER 8 (Hill and Wang 1973).

22. Id. at 3-11.

23. Id. at 113,119 .

24. Id. at 3-11. 
arbitrary. ${ }^{25}$ In his words, the "genesis of the commission and guidelines was a basic aversion to placing arbitrary power in the hands of any officials, including judges." 26

Frankel argued that to be lawful, sentencing decisions had to turn on "objective and objectively ascertainable criteria." 27 He advocated creating "a detailed chart or calculus," 28 to guide sentencing judges. This chart "would include, wherever possible, some form of numerical or other objective grading." 29 By limiting judicial discretion and creating numerical charts, sentencing commissions would decrease individualization in sentencing and as a result reduce sentencing disparity. Frankel placed great emphasis on the formal equality of defendants facing sentence. He cited the maxim, "the law is no respecter of persons" ${ }^{30}$ as a kind of watchword. By treating persons "as ... bland, fungible "equal[s],", ${ }^{31}$ guidelines would replace lawless with lawful sentencing.

Frankel also was critical of judges and had great faith in administrative agencies. He believed that sentencing commissions would create more equitable sentencing systems because they would be composed of people of prestige who would study sentencing and develop expertise concerning it. ${ }^{32}$ In contrast, at any given sentencing, a judge might be "punitive, patriotic, selfrighteous, guilt-ridden, and more than customarily dyspeptic." of sentencing commissions constraining judicial discretion resulted in "arbitrary cruelties perpetrated daily." 34 Thus, Frankel urged legislatures to create agencies to promulgate rules governing sentencing. Aided by computers, which Frankel believed would facilitate orderly thought, such agencies would make sentencing more rational. ${ }^{35}$

Frankel did not provide empirical support for his criticism of judicial sentencing discretion. He did not discuss actual sentences and cited no data in support of his view that disparity was so widespread that it justified his characterizing sentencing as lawless. Nor did he identify any substantive criteria for determining when a sentence was arbitrary. He simply asserted that "every prosecutor and defense lawyer knew"36 that judges sentenced

25. Id.

26. Frankel \& Orland, supra note 17, at 655.

27. FRANKEL, supra note 21, at 11.

28. Id. at 113.

29. Id. at 114.

30. Id. at 11 .

31. Id.

32. Id. at 118-24.

33. Id. at 23

34. Id. at 103 .

35. Id. at 115-16.

36. Frankel \& Orland, supra note 17, at 655. 
defendants based on personal evaluations rather than objective factors and concluded that sentencing was necessarily arbitrary and the results it produced unjust. ${ }^{37}$ The closest he came to discussing an actual sentence was his relation of an anecdote about a sentence that he considered arbitrary:

Judge $X$, to designate him in a lawyerlike way, told of a defendant for whom the judge, after reading the presentence report, had decided tentatively upon a sentence of four years' imprisonment. At the sentencing hearing in the courtroom, after hearing counsel, Judge $\mathrm{X}$ invited the defendant to exercise his right to address the court in his own behalf. The defendant took a sheaf of papers from his pocket and proceeded to read from them, excoriating the judge, the "kangaroo court" in which he'd been tried, and the legal establishment in general. Completing the story, Judge X said, "I listened without interrupting. Finally when he said he was through, I simply gave the son of a bitch five years instead of four." 38

This anecdote is striking because aside from the judge's injudicious characterization of the defendant, it is hardly self-evident that the judge behaved arbitrarily. Compared to the penalty that the federal sentencing guidelines impose for failure to accept responsibility, the punishment that the judge added for the defendant's insouciance is relatively mild. ${ }^{39}$

Frankel intended his book to be a call to arms to reduce judicial sentencing discretion, and he wrote it in a highly polemical style. He did not shy away from hyperbole, making such statements as: "the almost wholly unchecked and sweeping powers we give to judges in the fashioning of sentences are terrifying and intolerable for a society that professes devotion to the rule of law." 40 Frankel's rhetoric clearly influenced Kennedy, who embraced both Frankel's view that judicial discretion needed to be constrained and his rhetorical style. ${ }^{41}$ At various times, without citing any more evidence than Frankel did, Kennedy characterized sentencing in the federal courts as "a disgrace," "a national scandal," a "glaring flaw," in "utter disarray," "hopelessly inconsistent," "arbitrary," and "desperately in need of reform," and he became the principal Congressional proponent of sentencing guidelines. ${ }^{42}$ Finally, although Frankel was politically liberal and regarded sentencing as overly harsh - he called the United States 'the world's cruelest nation -

37. Id.

38. FRANKEL, supra note 21, at 18.

39. Under United States Sentencing Guideline $\S 3 E 1.1$, acceptance of responsibility is worth up to three points. Thus, a defendant who fails to accept responsibility typically faces a sentence nearly $30 \%$ longer than he otherwise would, see U.S. SENTENCING GUIDELINES Manual ch. 5, pt. A (sentencing table), a penalty greater than the $20 \%$ increase imposed by the intemperate Judge X.

40. FRANKEL, supra note 21 , at 5.

41. STITH \& CABRANES, supra note 5, at 38.

42. Id. 
cruelest in terms of incarcerating more people for longer periods than any other country" ${ }^{43}$ - he made a conscious decision not to take such harshness into consideration in his proposals for change. ${ }^{44}$ His priority was to change sentencing so that judges would be obliged to sentence defendants in conformity with an adjudicative model that he believed the rule of law required. While he hoped that in the long run sentencing commissions would "help educate legislators and the public to accept a more civilized (generally less harsh) sentencing regime," would not "alter our status as the world's cruelest nation." " In addition, he stated that if he had to choose, he would "choose less disparity, even with legislatively decreed harshness over wide discretion." ${ }^{47}$

\section{WHERE FRANKEL WENT WRONG}

As indicated, we believe that Frankel's analysis of sentencing and his proposed changes were flawed in a number of respects. In the following discussion, we advance three interrelated criticisms: first, in arguing that sentencing had to conform to a traditional adjudicative model - one involving detailed legislative or administrative directives and narrow judicial discretion Frankel mistakenly ignored that sentencing decisions dramatically differ from other judicial decisions; second, Frankel placed far too much emphasis on reducing disparity; and third, Frankel seriously erred by failing to address the problem of harshness. We discuss each of these points in turn.

\section{A. Sentencing is Different than Other Judicial Decision-Making}

In insisting that judges sentence defendants in conformity with an adjudicative model of the type that governs much judicial decision making - a model in which judges apply relatively specific rules and have limited discretion - Frankel ignored the differences between sentencing and other decision-making. We briefly discuss three differences.

First, judges usually resolve disputes in which the parties are legal if not actual equals, but this is not true when they sentence convicted criminals. Sentencing concludes a process during which one party, the state, has vastly more authority than the other, the defendant. In a criminal case, the state has the right to make a number of unreviewable decisions, one or more of which generally determine the outcome of the case. ${ }^{48}$ Prosecutors decide whether to

43. Frankel \& Orland, supra note 17 , at 655.

44. Id.

45. Id. at 662 .

46. Id. at 655 .

47. Id. at 662 .

48. See generally Ronald F. Wright \& Rodney L. Engen, The Effects of Depth and

Distance in a Criminal Code on Charging, Sentencing and Prosecutor Power, 84 N.C. L. REV. 
charge defendants and what charges to bring. They make recommendations with respect to pretrial release, which often determine whether defendants are released on bail. They decide what plea bargains to offer and what sentences to recommend. ${ }^{49}$ In many cases, one or more of these discretionary decisions are case-dispositive, either because of the weight judges give them or because defendants have no realistic choice but to accept them or for both reasons. ${ }^{50}$ In exercising their discretionary powers, prosecutors sometimes make wise choices and sometimes do not. Occasionally, they miss factors that a neutral observer would not. Sometimes, they overcharge defendants, decline to enter into reasonable plea agreements or recommend overly harsh sentences. ${ }^{51}$

Only judges can protect defendants from being punished excessively as a result of prosecutorial decisions, whether wise or unwise. No other realistic check on prosecutorial power exists. But judges cannot serve as counterweights to prosecutors without sufficient discretion. In advocating substantially reduced sentencing discretion, Frankel ignored the likelihood that his proposal would eliminate the most meaningful protection that many defendants possess.

Second, sentencing decisions differ from other judicial determinations in that the moral component of the decision is more central. ${ }^{52}$ The judge's goal is to arrive at a fair sentence, not to resolve a disputed legal issue. The maxim, "let the punishment fit the crime," refers to moral fitness. ${ }^{53}$ This is not to say that sentencing is not also legal. By definition, sentencing is a legal process carried out by legal actors within a legal institutional framework. ${ }^{54}$ But when deciding what sentence to impose, a judge seeks to resolve questions of moral culpability and how best to translate such culpability into an appropriate punishment. Because imposing a sentence is in substantial part a moral decision, the number of factors that may appropriately affect it is virtually unlimited, as are the weights that may properly be placed on such factors. ${ }^{55}$

1935, 1936-37 (2006) (explaining that the lack of legislative guidelines circumscribing prosecutorial discretion render many prosecutorial decisions unreviewable).

49. Id. at 1936.

50. See id. Defense counsel sometimes influence prosecutorial decisions but have no power to make decisions.

51. Occasionally, prosecutors recommend overly lenient sentences. This sometimes occurs when a prosecutor gets too close to a cooperating defendant.

52. See Kyron Huigens, Solving the Williams Puzzle, 105 CoLUM. L. REV. 1048, 1063 (2005) (stating that morally-credible outcomes are necessary to the maintenance of public support for the legal system and that "when we undertake to impose legal punishment in the form of onerous fines, imprisonment, or death, we attempt to match our legal judgments about wrongdoing as closely as possible to our moral judgments about wrongdoing").

53. Id. at 1071 .

54. Id. at $\mathbf{1 0 7 0 .}$

55. See Lynn Adelman \& Jon Deitrich, Fulfilling Booker's Promise, 11 RogER WILlIAMS U. L. REV. 521, 528-34 (2006) (discussing factors that sentencing judges consider in a postBooker landscape); see also R.A. Duff, Guidance and Guidelines, 105 COLUM. L. REV. 1162, 
Thus, a judge cannot determine an appropriate sentence by referring to a numerical chart or calculus as Frankel advocated. No numerical scheme can capture all of the factors that may affect a sentence, identify the relevant differences between individual cases and do justice to individual offenders. Any such scheme will inevitably lump together offenses that vary significantly and assign the same criminal history score to offenders whose relevant characteristics, culpability and prospects vary significantly. ${ }^{56}$

The problem is not only that numerical guidelines cannot capture many of the relevant differences between offenses, offenders and punishments, but also that they are in principle an unsuitable way of attempting to do so. ${ }^{57}$ This is so because the factors which may legitimately affect a sentence are so diverse that they cannot be represented as involving different quantities or degrees of some single basic value. Further, no mechanism can be formulated that will allow them to be compared or ranked on a single scale of value. ${ }^{58}$ Rather:

We must attend to the range of relevant factors, to the often subtle relationships between them, and to their significance in the particular context, and then try, through the exercise of a kind of judgment that is more akin to perception (seeing what is appropriate or what will make sense) than it is to calculation, to discern what we should do. It also follows that, while there will always be a number of possible actions that would be wrong, there will not always be only one action that can count as right. ${ }^{59}$

Thus, in advocating an adjudicative model that substantially limited judicial sentencing discretion, Frankel paid insufficient attention to sentencing's moral nature and to the complexities of the sentencing decision.

Sentencing differs from other judicial decision-making in a third way: sometimes, it is appropriate for a judge to grant mercy to an offender, i.e., impose a lesser sentence than justice would ordinarily demand. There are a variety of circumstances in which a judge might appropriately grant mercy. A defendant might have a serious health problem or be responsible for the care of a child or a sick or elderly family member. A defendant may, due to physical condition or other circumstances, be particularly susceptible to abuse in prison. ${ }^{60}$ A defendant might, after offending, have engaged in conduct

1173-81 (2005) (explaining that numerical sentencing guidelines fail "to recognize the irreducible diversity of values").

56. Duff, supra note 55, at 1173.

57. Id. at 1174

58. Id. at 1176

59. Id.

60. See, e.g., Koon v. United States, 518 U.S. 81, $111-12$ (1996) (explaining that a prisoner was more susceptible to prison abuse because of his public infamy and status as a former police officer); United States v. Lara, 905 F.2d 599, 605 (1990) (affirming a below guideline sentence for a defendant whose young appearance and bisexual orientation made him especially susceptible to 
evincing extraordinary and genuine remorse. ${ }^{61}$ Frankel understood that some judges could be "supremely humane," and he looked favorably on judges whose sentences reflected this quality. ${ }^{62}$ Yet, the changes in sentencing that he proposed left little room for mercy. ${ }^{63}$

\section{B. Over-Emphasizing the Elimination of Disparity}

Frankel also erred in placing so much emphasis on eliminating sentencing disparity. Neither disparity nor its opposite, uniformity, are self-defining concepts, and both can serve any master. ${ }^{64}$ To have any meaningful content, both concepts require the elaboration of some underlying theory of sentencing, i.e., some notion of what sentences should accomplish. ${ }^{65}$ For example, a theory of sentencing might emphasize deterrence, incapacitation, rehabilitation, just desserts or some combination of some or all of these purposes. ${ }^{66}$ Ultimately, we want judges to impose reasonable sentences and to arrive at them through a reasoned process. ${ }^{67}$ In the absence of substantive ideas concerning what makes a sentence reasonable, the concepts of eliminating disparity and achieving uniformity are empty. Frankel did not accompany his insistence on eliminating disparity with substantive ideas about sentencing. $\mathrm{He}$ left to others "the important policy problems of sentencing"68 such as those mentioned above. As a result, the centerpiece of his proposed reform, the concept of eliminating disparity, had no intrinsic meaning and was essentially empty.

To the extent that Frankel made policy arguments in support of eliminating disparity, he contended that it would benefit defendants ${ }^{70}$ and

inmate victimization).

61. Adelman \& Deitrich, supra note 55, at 529-30. We understand that retributivists do not think that such exercises of sentencing discretion should be characterized as grants of "mercy." See Dan Markel, Against Mercy, 88 MINN. L. REV. 1421, 1468-69 (2004). However, whatever label is applied to such exercises of discretion, most students of sentencing agree that judges should be able to grant leniency in these and similar situations.

62. Frankel \& Orland, supra note 17 , at 663.

63. It probably goes without saying that many defendants are not entitled to mercy.

64. Kevin Cole, The Empty Idea of Sentencing Disparity, 91 Nw. U. L. REV. 1336, 1336-37 (1997).

65. Id. at 1336.

66. See O'Hear, supra note 16 , at 753 (listing the traditionally recognized purposes of sentencing).

67. Panel Remarks, Is Guided Discretion Sufficient?, 44 ST. LOUIS U. L.J. 447 (2000) (commentary by Kate Stith).

68. O'Hear, supra note 16 , at 759.

69. O'Hear suggests that Frankel's avoidance of difficult issues contributed to his influence. $I d$. at 762. This may well be true, but in our view, it contributed to the fact that his influence was mostly negative.

70. Id. at 760 . 
increase the public's respect for the justice system. ${ }^{71} \mathrm{He}$ asserted that numerical guidelines would benefit defendants by respecting their dignity, providing them with fair notice and decreasing their sense of resentment. ${ }^{72} \mathrm{He}$ further asserted that numerical guidelines would engender public confidence because "the splatter of varied sentences, with the unexplained variations . . nourishes the view that there is no justice in the law.",73

We have no quarrel with eliminating disparity but reiterate that, without more, it is a largely meaningless concept. Moreover, for several reasons, Frankel's arguments that eliminating disparity through numerical guidelines would in itself benefit defendants and the public are unpersuasive.

First, although Frankel offered anecdotal evidence of prisoner resentment based on perceptions of disparity ${ }^{74}$ (and Congress later accepted that "disparities fed prisoner resentment and impeded rehabilitation"), ${ }^{75}$ we are unaware of studies supporting this notion. ${ }^{76}$ Further, to the extent that a defendant's perception of the fairness of his treatment may affect his adjustment to prison and rehabilitation, the way to deal with the problem is for judges to explain the bases for their sentences and thereby humanize the process, rather than to require that judges sentence defendants based on a numerical chart. ${ }^{77}$

Second, Frankel's notion that numerical guidelines would benefit defendants was flawed because, as we will discuss in more detail in the next section, the politics of sentencing are such that numerical guidelines will always tilt high. Thus, if in a nonguideline regime two similarly situated defendants receive different sentences, under a system of numerical guidelines, it is more likely that the defendant who received the lower sentence will receive a higher sentence than the reverse. ${ }^{78}$ In fact, it is likely that both defendants

71. Id. at 792.

72. Id. at 760-61.

73. Id. at 792 (quoting FRANKEL, supra note 21, at 44).

74. FRANKEL, supra note 21, at 17 (recounting a conversation with a warden); see also Stephen J. Schulhofer, Due Process of Sentencing, 128 U. PA. L. REV. 733, 734 (1980) (stating that disparity in sentencing "promote[s] resentment among prisoners, thereby increasing their sense of alienation and mistrust," but citing only Frankel's book in support); Stanley A. Weigel, Appellate Revision of Sentences: To Make the Punishment Fit the Crime, 20 STAN. L. REV. 405, 410 (1968) (relying on anecdotal evidence to claim that "resentment inevitably breeds unrest and disciplinary problems, and, in addition, may well undermine his reformation"). Interestingly, the more recent anecdotal evidence of prison unrest due to disparity relates to differences between federal and state penalties for similar conduct. See, e.g., Steven D. Clymer, Unequal Justice: The Federalization of Criminal Law, 70 S. CAL. L. REV. 643, 677 n.181 (1997).

75. Stephen J. Schulhofer \& Ilene H. Nagel, Negotiated Pleas Under the Federal Sentencing Guidelines: The First Fifteen Months, 27 AM. CRIM. L. REV. 231, 237 (1989).

76. See Lynn Adelman \& Jon Deitrich, Disparity: Not a Reason to "Fix" Booker, 18 FED. SENT'G REP.160, 161 (Feb. 2006).

77. Some defendants may resent being reduced to a number on a grid.

78. Adelman \& Deitrich, supra note 76, at 161. 
will receive higher sentences. ${ }^{79}$ This outcome, of course, benefits neither defendant. In practice, numerical guidelines simply mean longer sentences for most defendants. ${ }^{80}$

Third, Frankel's contention that eliminating disparity would increase public confidence in the justice system is unconvincing. If anything, the converse is true. Arguably, the public is more likely to disrespect a system that trivializes judges' powers and reduces the role of judges to calculating numbers and imposing pre-established sentences. The sentencing guidelines reduced judges' powers and hardly resulted in an increase in public confidence. Stith and Cabranes describe how the public viewed a sentencing hearing under the guidelines:

[A]fter thirty or forty minutes of [guideline] double-speak, the sentencing judge realizes that parties and spectators in the courtroom are staring ahead in dazed numbness, having lost all sense of what is happening. That is when the judge feels bound to pause, to try to reassure courtroom observers, in comprehensible language, that the principal interlocutors in the courtroom do indeed understand what they are talking about, and that what is going on, though perhaps unintelligible to them, is indeed honest and fair. ${ }^{8}$

Finally, in focusing so heavily on eliminating disparity through numerical guidelines, Frankel ignored a number of potential problems, including the problem of harshness and the fact that numerical guidelines miss important differences between defendants. ${ }^{82}$ As to the latter, Frankel's proposed scheme required sentencing judges to consider only objective factors, such as the amount that a defendant stole or the weight of the drugs that he possessed. Frankel depreciated the importance of less tangible factors such as a defendant's motive, intent, character or personal circumstances. The inevitable consequence of barring judges from considering such factors is that it forces them to treat identically defendants whose culpability differs. For example, a judge must punish equally a defendant who steals to finance a child's operation and a defendant who steals the same amount out of greed. In other words, numerical guidelines require bright-line rules. A system of bright-line rules is an inflexible one. Frankel ignored this problem, and rigidity became a hallmark of the guidelines.

\section{Ignoring Our History of Harshness}

Perhaps Frankel's most serious error was his decision to ignore America's history of harsh sentencing. Although, as indicated, he was well aware of this

\footnotetext{
79. Id.

80. Id.

81. STITH \& CABRANES, supra note 5, at 85.

82. We will address the problem of harshness in the next section.
} 
history, he did not factor it into his proposed reform. Rather, he stated that "guidelines [were] not designed to mitigate severe sentences ... [ [but] to cure lawlessness." 83 He never explained why he thought that disparity which, with typical hyperbole, he characterized as lawlessness, was a more serious problem than harshness. However, the fact that he did illustrates as much as anything else the fundamental problem with his approach to sentencing - it was abstract, legalistic and insufficiently attentive to the sentences that defendants actually received.

Frankel's failure to take harshness into consideration can be faulted on several levels. First, reactionary anti-judge and anti-judicial discretion attitudes had been circulating widely in the United States since the Supreme Court decided Brown v. Board of Education in 1954. ${ }^{84}$ As Naomi Murakawa has shown, one of the dominant themes in conservative politics after the Supreme Court decided Brown and subsequently made other controversial decisions in the areas of civil and political rights and criminal procedure, was that federal judges had too much power and that Congress should take action to curb it. ${ }^{85}$ Frankel took no note of this development and made no effort to distinguish his own opposition to judicial discretion and his own criticism of judges from these attitudes and themes.

Further, as open expression of racism became increasingly unacceptable, some politicians adopted rhetoric that might reasonably be construed as encouraging the displacement of racial animosity onto criminals. ${ }^{86}$ At the Republican National Convention in 1964, which in Meg Greenfield's words, "reek[ed] of hostility to a civil rights bill," ${ }^{87}$ Barry Goldwater electrified the

83. Frankel \& Orland, supra note 17 , at 659.

84. Naomi Murakawa, The Racial Antecedents to Federal Sentencing Guidelines, How Congress Judged the Judges from Brown to Booker, 11 ROGER WILLIAMS U. L. REV. 473, 481-84 (2006).

85. Murakawa points out that:

Attacks on the racially liberal judge set in the 1950 s retained prominence through the sentencing revolution, and the rhetoric against judicial lenience shifted from lenience with blacks to lenience with criminals. By the time Congress mandated creation of Sentencing Guidelines in 1984, attacks on the racially liberal judge had gained even more credibility with Warren Court decisions that were widely perceived as pro-black, pro-Communist, and pro-criminal. It is commonly noted that Federal Sentencing Guidelines garnered support from liberals like Senator Kennedy as well as conservatives like Senators McClellan and Thurmond, but this article does more than show how liberals wanted rationalized moderate sentences while conservatives wanted rationalized harsh sentences. Instead, this article suggests that support for Sentencing Guidelines goes deeper than preferences on sentencing; that is, there is a deeper and decidedly racial legacy to attacking judicial discretion. In attacks on liberal judges from Brown to Booker, Congress has judged the judges for transgressing racial guidelines.

Id. at 481-494.

86. See $i d$. at 492.

87. MEG GREENFIELD, WASHINGTON 189 (2001). 
attendees by denouncing the "growing menace" to personal safety. ${ }^{88}$ And in his State of the Union speech in 1970, President Nixon stated that we must "win the war against criminal elements which increasingly threaten our cities, our homes and our lives." $" 89$ In keeping with the increasingly politicized nature of criminal justice policy, legislators downgraded the importance of research, knowledge and serious analysis of the type that Frankel proposed. ${ }^{90}$ Rather, they increasingly subjected policy-making in the field of criminal justice to partisan considerations. ${ }^{91}$ As indicated, Frankel was a liberal who had no interest in joining the war on judges or the war on crime (which wars became virtually indistinguishable). Nevertheless, his vehement attacks on judicial sentencing discretion, his proposal to increase legislative involvement in criminal sentencing and confer sentencing authority on administrative agencies, and his failure to address the problem of overly harsh sentencing dovetailed nicely with the conservatives' themes and with their goal of making criminal sentences even harsher than they already were. ${ }^{92}$

At a deeper level, Frankel's decision not to think seriously about harshness prevented him from recognizing the connection between harshness and the philosophy of formal equality that he enthusiastically espoused. ${ }^{93}$ As James Whitman points out, the maxim that the law is no respecter of persons, which Frankel liked to quote, has more than one meaning. To Frankel, it meant that sentencing judges should be required by law to "treat all persons precisely alike regardless of personal characteristics." 94 This would prevent judges from showing more concern for some offenders, presumably whites, than for others, presumably African-Americans. Frankel's program might have been unobjectionable if it had been likely that legislatures and sentencing commissions would not establish unnecessarily harsh punishments. However, this has not been the American pattern. ${ }^{95}$ The second meaning of the maxim that the law is no respecter of persons is that the law treats no "offenders with respect." 96 Whitman has shown that in contrast to continental democracies,

88. GOTTSCHALK, supra note 19 , at 237.

89. PAGER, supra note 19 , at 9.

90. See GARLAND, supra note 19, at 13-14.

91. Id.

92. Some may suggest that Frankel could not, in the early 1970 s, have anticipated the harsh criminal justice policies that characterized the Reagan and post-Reagan era. See, e.g., STITH \& CABRANES, supra note 5, at 43 (discussing the political reconfiguration of Washington in the $1980 \mathrm{~s}$ ). Although it is true that policies became harsher in the 1980s and 1990s, at the time that Frankel commenced his crusade, the trend in sentencing was clear. In fact, in the same year that Frankel published his book, 1973, his home state of New York enacted the infamous Rockefeller drug laws, which mandated draconian sentences in even minor drug cases. See Darryl K. Brown, Democracy and Decriminalization, 86 TEX. L. REV. 223, 268 n.214 (2007).

93. See WHTMAN, supra note 19, at 55.

94. Id. at 42 .

95. Id. at 223 n.72.

96. Id. at 43 . 
America tends to treat offenders as low-status persons who deserve to be punished harshly. ${ }^{97}$ Frankel ignored this fact. And, of course, the guidelines became known more for treating everybody harshly than for treating everybody equally.

Why America tends to punish so harshly is a complicated subject that is beyond the scope of this article. However, one reason is obvious: many politicians believe that they can mobilize support by advocating harsh treatment of criminals and will enact ever harsher legislation in order to do so. There is "an intimate nexus between the politics of mass mobilization, unchecked by bureaucracy, and the making of harshness in criminal punishment." 98 This is so in substantial part because voters never see individual offenders and thus have no opportunity to feel empathy or compassion. ${ }^{99}$ Whitman has shown that continental politicians have been less successful than their American counterparts at mobilizing demands for harshness because in Europe, civil servants with long-standing commitments to individualized sentencing and mercy have greater autonomy, retain control of the rules governing punishment and serve as bulwarks against such demands. ${ }^{100}$ The only potential bulwarks against harshness in the American criminal justice system are reasonable prosecutors, judges with sufficient discretion and parole boards. The latter two are the entities that in the name of formal equality and for the purpose of eliminating disparity Frankel sought to weaken.

Thus, Frankel, who favored more humane punishment, unwittingly became an advocate for harsher sentences. He did not distinguish between treating all persons equally and treating all persons harshly, and he gave no thought to the fact that the American criminal justice system also did not. $\mathrm{He}$ also encouraged harshness by ignoring that guidelines themselves encourage a shift away from mercy in sentencing. Mercy can only be granted when sentencing is individualized. This is so because "mercy is something you feel; it is not something that can be laid out in advance in general rules."101 Although Frankel was interested in creating a system which showed greater respect for defendants, ${ }^{102}$ his decision not to address the issue of harshness contributed to the creation of a law of punishment that manifests little regard for the dignity of offenders but simply incarcerates them. ${ }^{103}$

97. Id. at 85 (offering a subtle but powerful explanation of the differences between continental and American patterns of punishment).

98. Id. at 15 .

99. Id. at 55 .

100. Id. at 15 .

101. Id. at 55 (citing PIERRE FranCOIS MUYART De Vouglans, Refutation du Traite des Delits et Peines, etc, in LOIX CRIMINELLES 811 (orig. 1776)).

102. O'Hear, supra note 16 , at 760.

103. WHITMAN, supra note 19 , at 223 n.72. 


\section{EFFECTS OF FRANKEL'S IDEAS}

When Congress enacted the SRA and the Commission promulgated the guidelines, Frankel realized his goal of reducing judicial sentencing discretion. Unsurprisingly and, as he should have anticipated, one result was to increase the power of prosecutors over sentences. Judges could no longer serve as a bulwark against the consequences of prosecutors' charging decisions, even when they found those consequences objectionable. Under the guidelines, prosecutors, who are advocates, largely controlled the severity of sentences through charging decisions and plea offers, and judges, who are neutrals, often had to impose sentences that they believed were unfair. ${ }^{104}$

A related adverse consequence which, as we have discussed, Frankel also should have anticipated, was a dramatic increase in the harshness of sentences. This consequence resulted both from the guidelines that the Commission adopted and the constraints the Commission imposed on judicial discretion. Under the guidelines, the length of the average federal sentence increased from twenty-eight to fifty months, ${ }^{105}$ and the average time served by a defendant rose from thirteen to forty-three months. ${ }^{106}$ In addition, the guidelines prohibited probation in most cases. ${ }^{107}$ Thus, instead of a system in which judges imposed harsh sentences idiosyncratically, Frankel's ideas led to the creation of a system in which harshness became "a rule of law."108

Although Frankel expressed hope that sentencing commissions would serve as bulwarks against harshness, ${ }^{109}$ he proposed nothing that would have made this likely to occur. Moreover, as he should have understood, commissions are appointed by elected officials, and their members are mindful of elected officials' opinions. As previously mentioned, the original members of the federal commission viewed the Justice Department and the most lawand-order members of Congress as their primary constituency. ${ }^{110}$ Nor has the

104. See Adelman \& Deitrich, supra note 76, at 160.

105. Id.

106. Id.

107. See, e.g., Marc. L. Miller, Domination \& Dissatisfaction: Prosecutors as

Sentencers, 56 STAN. L. REV. 1211, 1222 (2004) ("Before the guidelines, almost 50\% of

federal sentences were to straight probation. Under the initial guidelines, that figure dropped to around $15 \%$.").

108. See Frankel \& Orland, supra note 17, at 661. Orland opines that, "harshness imposed by a sentencing commission is far worse than idiosyncratic harsh sentences imposed in an age of discretion because a guideline system imposes harshness as a rule of law."

109. Id. at 662-63.

110. Tonry states that in its early years, the functions of the Commission "became entangled in the personal ambitions of William Wilkins, the first chair (initially unsuccessfully to become FBI director, then successfully to become an appellate judge), and Stephen Breyer (successfully to get to the Supreme Court). This meant that a major function of the Guidelines was to win favor with Strom Thurmond and his personal staff in the Senate in particular, with Congressional Republicans more generally, and with Ed Meese's Justice Department." Michael Tonry, The Functions of Sentencing \& Sentencing Reform, 58 STAN. L. REV. 37, 65 (2005). 
Commission changed much over the years. ${ }^{111}$ Its concern about the responses of the Department of Justice and its allies in Congress to its decisions has greatly affected its decisions relating to policy. ${ }^{112}$

Generally speaking, state sentencing commissions also failed to withstand demands for harshness. Stith describes the fate of Frankel's ideas at the state level as follows: "the transformation of Senator Kennedy's bill on the federal level is similar to what happened to state criminal justice legislation. . . . The new sentencing regimes were more responsive to a concern with overly lenient sentences by soft-hearted judges than they were" to fairness and due process concerns. ${ }^{113}$ And, although commissions in a few states such as Washington and Minnesota managed to keep prison populations under control for a while, legislators ultimately enacted laws compelling the commissions to enact harsher penalties. ${ }^{114}$

The guidelines' failure also made it clear that any proposed sentencing reform that makes the reduction of inter-judge sentencing disparity its principal goal, as Frankel's did, is a "major mistake." minimize inter-judge sentencing disparity will possess the flexibility to facilitate fair sentences. Nor will it eliminate disparity. This is so because there are many sources of disparity other than judicial discretion. Much disparity is the product of regional differences, ${ }^{116}$ and much is caused by differences in prosecutorial policies. ${ }^{117}$ Further, rules designed to promote uniformity can for a variety of reasons actually lead to greater disparity. Under the guidelines, the most pernicious sort of disparity - racial disparity - has actually increased. ${ }^{118}$ The average sentence of an African-American defendant today is about twentyfive percent higher than a white defendant. ${ }^{119}$ A recent Commission report attributes this increase not to the exercise of sentencing discretion by judges, but to:

\section{An 'institutionalized unfairness' built into the sentencing rules}

111. See Bowman, supra note 4, at 263.

112. See id. at 253-56. In fairness to the Commission, we note and applaud its recent important decision to apply the two-level reduction in crack cocaine cases retroactively. See U.S. SENTENCING GUIDELINES MANUAL $§ 1 B 1.10$ (c) (2008).

113. Kate Stith, Panel Remarks, Sentencing Guidelines: Where We Are and How We Got Here, 44 ST. LoUIS U. L.J. 387,388 (2000).

114. Tonry, supra note 3 , at 720. State sentencing commissions sometimes sought to keep prison populations down in order to avoid "out-of-control corrections spending and federal court intervention." $I d$.

115. Stith, supra note 67 , at 447.

116. See Ian Weinstein, The Historical Roots of Regional Sentencing Variation, 11

ROGER WILLIAMS U. L. REV. 495 (2006).

117. See, e.g., Frank Bowman, et al., Panel II: The Effects of Region, Circuit, Caseload and Prosecutorial Policies on Disparity, 15 FED. SENT'G REP. 165, 170 (2003)

118. Lynn Adelman \& Jon Deitrich, Rita, District Court Discretion and Fairness in Federal Sentencing, 85 DENV. U.L. REV. 51, 56-57 (2007).

119. Id. 
themselves. . . . Today's sentencing policies, crystallized into the sentencing guidelines and mandatory minimum statutes, have a greater impact on Black offenders than did the factors taken into account by judges in the discretionary system in place immediately prior to guideline implementation. ${ }^{120}$

Notwithstanding the failure of reform proposals focused on eliminating sentencing disparity, Frankel's ideas have had a powerful impact on the thinking of many people involved in sentencing, including judges, lawyers and probation officers, ${ }^{121}$ an impact that we see as largely negative. Many such individuals seem to believe that the extent to which disparity is avoided rather than substantive fairness is the principal measure of an appropriate sentence. Judge Gertner has commented on how deeply ingrained in the minds of judges the preoccupation with uniformity has become:

The Guidelines essentially supplanted everything. It was almost as if we could no longer speak about anything else .... As one judge in Oregon ... describes it, 'It's as if the only thing we are talking about is whether I am doing the same thing as Judge Adelman is doing, even if we are both wrong., 122

The response to one of Judge Adelman's decisions, United States v. Galvez-Barrios, ${ }^{123}$ illustrates how in the minds of many judges avoiding disparity supplanted other measures of sentencing fairness. Galvez-Barrios involved a sentence for a violation of 8 U.S.C. $\S 1326$, unlawful re-entry after deportation. The decision made two points. It placed primary emphasis on the proposition that the Commission's 16-level guideline enhancement for re-entry after conviction for an aggravated felony was too harsh. It explained that the Commission had neither adequately thought through nor justified the enhancement. ${ }^{124}$ As a subsidiary point, the decision noted the disparity between the sentences called for by the guidelines in $\S 1326$ cases and those imposed in districts with "fast-track" programs, which involve reduced sentences in return for prompt guilty pleas. ${ }^{125}$ Many judges responded to the decision, but all responded to the point about disparity and none to the conclusion that the 16-level enhancement was too harsh.

Thus, judges are excessively attuned to the notion of uniformity and insufficiently responsive to critiques of the guidelines based on substantive fairness. This may be in part because many judges are unaccustomed to non-

120. UNITED States SENTENCING COMMISSION, FifTEEN YeARs OF GUIDELINES Sentencing (An Assessment of How Well the Federal Criminal Justice System Is ACHIEVING THE GOALS OF SENTENCING REFORM) 135 (2004).

121. See, e.g., Panel Discussion, supra note 14, at 14.

122. Panel Discussion, supra note 14, at 5-7.

123. 355 F. Supp. 2d 958 (E.D. Wis. 2005).

124. Id. at 961-63.

125. Id. at 963. 
guideline sentencing and may believe they lack the knowledge or experience to criticize the guidelines. Many judges may also believe it is inappropriate for them to do so. ${ }^{126}$ However, it is also true that the formal egalitarianism, which Frankel championed, has "immense power" in the culture of American criminal justice. ${ }^{127}$ And sentencing in a world in which that idea is ascendant, i.e., the world of the guidelines, will inevitably be a harsh business, with little room for mercy. ${ }^{128}$

Frankel's ideas have adversely affected judges in another way. They have made them less thoughtful sentencers. Sentencing under numerical guidelines is relatively easy because it requires little reasoning. ${ }^{129}$ Judges need not think through the often difficult questions of how the various purposes of sentencing relate to each other in a particular case. Their principal obligation is to calculate the applicable number - a task that generally is a mechanical one. As a result, judges are less able to perform the task of "practical reasoning" in a specific factual context that effective sentencing requires. ${ }^{130}$

\section{CONCLUSION}

We understand that criticism is easy with the benefit of hindsight. Nevertheless, in reading Frankel today we find his outrage at the then-existing sentencing system excessive and the system that he envisioned unattractive. We are struck by the ease with which he set aside the problem of harshness in sentencing and focused instead on an idealized conception of lawfulness, which had at its center an undefined notion of uniformity. We also believe that he was excessively skeptical of judges' ability to impose fair sentences. Further, we see his proposal to create a commission of "prestige and credibility"131 composed of "people of stature, competence, devotion and eloquence," 132 to promulgate numerical guidelines governing sentencing as suffering from a kind of "best and brightest" mentality. ${ }^{133}$ Finally, he overlooked the fact that it was

126. See Panel Discussion, supra note 14, at 11, where Judge Richard G. Kopf expressed the view that judges lack competence to "put together a coherent, analytical sentencing method" and thus should give the guidelines "substantial weight."

127. WHITMAN, supra note 19, at 54.

128. Id. at 55 .

129. Although the federal guidelines call upon judges to sentence within a range, the ranges are very narrow. See 28 U.S.C. $\$ 994(b)(2)$ (2001 \& Supp. 2008) (providing that the maximum of an imprisonment range shall not exceed the minimum by more than the greater of $25 \%$ or 6 months).

130. See Duff, supra note 55, at 1170-71 (stating that numerical guidelines are attractive to those who mistrust "the impartiality or practical reasoning skills of sentencers" and to those "who attach great weight to the ideal of uniformity in sentencing"). Frankel falls into both categories.

131. FRANKEL, supra note 21, at 119.

132. Id. at 119-20.

133. See DAVID HALBERSTAM, ThE BEST AND THE BRIGHTEST (1972) (relating how an intellectual and political elite led us into a quagmire in Vietnam). Interestingly, Frankel delivered 
highly unlikely that any legislature or commission would create a system of numerical guidelines that did not give prosecutors too much power, did not result in overly harsh sentences and did not turn sentencing into a relatively mechanical affair. Thus, it is not unfair to conclude that Frankel bears considerable responsibility for the guidelines' failure.

We conclude with a few words about the future. In our view, it would be desirable to discard Frankel's approach and scrap numerical guidelines altogether. We do not advocate returning to the pre-guidelines regime but favor a different type of guideline system - what one thinker calls "discursive guidelines."134 Such guidelines would not include numbers but would specify the types of punishment available for an offense (presumably they would provide more options than the present guidelines which focus almost exclusively on prison), the goals sentencers should seek to accomplish, and the criteria and considerations relevant to such goals. ${ }^{135}$ However, they would leave to individual judges the task of determining precisely how to weigh the relevant goals, criteria and considerations in individual cases. ${ }^{136}$ This type of guideline system could build on the factors identified in 18 U.S.C. $\$ 3553(\mathrm{a}),{ }^{137}$ which we find a useful statute. Discursive guidelines would make more stringent demands on judges than the present system does. Judges could no longer rely on a pre-established number and would have to provide more detailed explanations of their sentences to the parties, the public and appellate courts than they presently do. ${ }^{138}$ As a result, judges would become more thoughtful and fair sentencers.

We recognize, however, that Congress and the Commission will likely retain the present system. Further, we fear that notwithstanding the Supreme Court's welcome (and, from the standpoint of where we were not long ago, astonishing) decisions in Booker, ${ }^{139}$ Rita $^{140}$ Gall $^{141}$ and Kimbrough, ${ }^{142}$

the lectures that led to his book in the same year that Halberstam published his famous work.

134. Duff, supra note 55, at 1168-79. For a general discussion of discursive guidelines, see id. at $1168-1179$.

135. Regarding such options, see Demleitner, supra note 20.

136. Duff, supra note 55, at 1169.

137. Section 3553(a) directs the sentencing court to consider, in addition to the

Commission's guidelines and policy statements, the nature and circumstances of the offense and the history and characteristics of the defendant; the need for the sentence imposed-(A) to reflect the seriousness of the offense, to promote respect for the law, and to provide just punishment for the offense; (B) to afford adequate deterrence to criminal conduct; (C) to protect the public from further crimes of the defendant; and (D) to provide the defendant with needed educational or vocational training, medical care, or other correctional treatment in the most effective manner; the kinds of sentences available; the need to avoid unwarranted sentence disparities; and the need to provide restitution to any victims of the offense. 18 U.S.C. $\$ 3553$ (a) (2006).

138. Duff, supra note 55 at 1189.

139. United States v. Booker, 543 U.S. 220, 245 (2005) (making the guidelines "effectively advisory").

140. Rita v. United States, 127 S. Ct. 2456, 2465 (2007) (stating that while appellate courts 
judges will be excessively cautious about exercising their newly-granted discretion and continue to adhere closely to the guidelines. One reason for our concern is the psychological phenomenon known as anchoring, which Judge Lynch described as follows:

When you have got a question that's very subjective that people are called upon to answer and you give them a number as kind of a baseline, that number is very helpful. Whether people like that number or not, even if they are angry about that number, does not matter; they will still be influenced by that number. That is the psychological fact. I think it is psychologically inevitable that the Guidelines will have a powerful influence on sentences, even if they are purely advisory, because they put a number on a question that is otherwise quite subjective. ${ }^{14}$

Nevertheless, the Supreme Court has created a system that at least has the potential to be just because it permits judges to treat defendants as individuals, to consider all of the circumstances of a case, and to ameliorate the harshness and rigidity of the guidelines.

We conclude by briefly discussing an idea of Frankel's that we can heartily endorse. Frankel thought it important to improve communication between judges about sentencing. ${ }^{144}$ We agree and think this idea is particularly important now that the Supreme Court has returned discretion to district judges. Although most judges would probably agree that sentencing is one of the most important things they do, there is virtually no continuing education for judges about the actual practice of sentencing, no lectures, workshops, conferences or retreats. The Commission would be the obvious entity to sponsor such activities as it is technically a judicial branch agency. However, the Commission is heavily invested in the guidelines and has shown little inclination to open-mindedly explore different points of view about how judges should exercise their newly-conferred discretion. If, however, it could reinvent itself and get past its "follow the guidelines" mindset, the Commission could perform a valuable service as a facilitator of communication. More interaction among judges about sentencing would likely make judges less reluctant to critique the guidelines and sentence outside them. Possibly it would also lead to greater convergence in sentencing practices. In sum, it

may presume a guideline sentence reasonable, sentencing judges may not do so).

141. Gall v. United States, 128 S. Ct. 586, 597 (2007) (adopting deferential abuse of discretion standard of appellate review of non-guideline sentences, and affirming sentence of probation despite guideline range of 30-37 months imprisonment)

142. Kimbrough v. United States, 128 S. Ct. 558, 575 (2007) (permitting district courts to disagree with the guidelines' harsher treatment of crack than powder cocaine).

143. Panel Discussion, supra note 14, at 17-18.

144. Admittedly, he thought that improving communication was much less important than subjecting sentencing to "a system of law." FRANKEL, supra note 21, at 66. 
might represent a small but not insignificant step toward achieving both our goals and Frankel's. 